\title{
Pelatihan Pengambilan Keputusan Menggunakan Metode PACED pada Pelaku Usaha
}

\author{
Ramayani Yusuf $^{1 *}$, Rita Zulbetti ${ }^{2}$, Yunyun Ratna ${ }^{3}$, Ai Susi Susanti ${ }^{4}$ \\ ${ }^{1}$ Universitas Pendidkan Indonesia, ${ }^{2,3,4}$ Politeknik Piksi Ganesha \\ *yusuframayani@gmail.com
}

\begin{abstract}
Abstrak
Pelatihan ini bertujuan untuk memberikan gambaran pengambilan keputusan menggunakan metode PACED ( Problem, Alternative, Criteria, Evaluated and Decision ) pada pelaku usaha di Surabaya. Metode PACED merupakan metode yang dikembangkan oleh YEP USAID dalam memberikan pelatihan literasi keuangan. Tahap pertama metode ini adalah menentukan problem/ masalah yang menjadi tujuan kita, kemudian dicari alternative dari masalah tersebut, dicari kriteria yang memudahkan kita menentukan pilihan, lalu dievaluated dengan cara diberi poin setiap kolom yang terhubung antara alternatif dan kriteria. Jumlahkan hasil dari pemberian poin tersebut. Alternatif yang mendapat nilai terbesar merupakan keputusan dari problem. Metode PACED ini diberikan kepada pelaku UKM yang mendapat bantuan mikro dari pemerintah senilai 2,4 juta rupiah. Alternatif yang diberikan adalah : membeli mesin produksi, membuat konten digital marketing, membeli bahan baku dan membuat event marketing. Kriteria yang diberikan adalah: biaya $0-1$ juta, biaya $1,1-2,4$ juta, memerlukan waktu yang lama, menutupi biaya operasional, dan memberikan kelangsungan usaha. Dari 26 orang yang mengikuti kegiatan pelatihan $80 \%$ memilih membuat konten digital marketing untuk kelangsungan usaha mereka.
\end{abstract}

Kata Kunci: pelatihan, pengambilan keputusan, metode PACED, pelaku usaha

\section{Decision Making Training Utilising The PACED Method for Business Players}

\begin{abstract}
The objective of the training is to provide an overview of decision-making process using the PACED (Problem, Alternative, Criteria, Evaluated and Decision) method for business players in Surabaya. The PACED method is developed by YEP USAID to meet the need of financial literacy improvement training. The first stage of this method is to determine the problem which then is translated to our goal, then look for alternatifs to solve the problem, identify the criteria that make it easier for us to make choices, then evaluated by setting a point for each column that is connected between alternatifs and its criteria. Then, sum up all of the points awarded. The alternatif that gets the biggest score becomes the decision to solve the problem. The PACED method is applied to the SMEs who received financial assistance from the government worth 2.4 million rupiah. The funds must be allocated for certain business alternatifs, such as purchasing production machines, raw materials, creating digital marketing content and (marketing) events. The criteria are: cost requirement 0-1 million, cost requirement 1.1-2.4 million, require a long time, covering operational costs, and provide business sustainability. From 26 participants who took part in the training activities, $80 \%$ chose to create digital marketing content for their business sustainability.
\end{abstract}

Keywords: course, dicision making, PACED method, enterpreuner

\section{PENDAHULUAN}

Meningkatnya penyebaran virus Corona membuat pemerintah Indonesia harus mengambil berbagai kebijakan, seperti penerapan pembatasan sosial (social distancing) hingga pemberlakuan Pembatasan Sosial Berskala Besar (PSBB) di sejumlah daerah. Kebijakan tersebut ditandai dengan lahirnya Peraturan Pemerintah (PP) Nomor 21 Tahun 2020 di mana pelaksanaan ibadah, bekerja, termasuk kegiatan belajar mengajar harus dilakukan dari rumah serta menghindari kerumunan massa begitu juga larangan pelaksanaan kegiatan yang sifatnya dapat mengundang atau mengumpulkan massa (Purnamasari, 2020) 
Vol. 2, No. 1, March, 2021, pp. 50-56

e-ISSN: 2722-2004

Decision

Making

Training

Utilizing The

PACED

Method

for Business

Players

F. Jumawan,

W. Darmawan,

A. F. Tamrin

PSBB ini mengakibatkan terhentinya sebagian besar kegiatan perekonomian, salah satunya adalah berkurangnya kegiatan perkantoran yang berdampak pada menurunnya produktivitas dan menurun juga transaksi perdagangan. Bagi pelaku usaha hal ini menyebabkan menurunnya pendapatan, banyak pelaku usaha akhirnya gulung tikar karena tidak mampu menutupi biaya operasional.

Tugas besar ada di pundak Pemerintah Indonesia terkait dengan pandemi Covid-19 saat ini: pertama, menjaga keselamatan dan kesehatan masyarakat Indonesia sebagai fokus utama dan kedua, menjaga laju pertumbuhan ekonomi. Prediksi pertumbuhan ekonomi global perlu dijadikan input bagi pemerintah dalam merancang kebijakan-kebijakan ekonomi terutama solusi bagi UMKM (Pakpahan, 2020).

Di Pasal 11 Perppu Nomor 1 Tahun 2020, dinyatakan, untuk pelaksanaan program penyesuaian keuangan negara dan stabilitas ekonomi, suatu peraturan pemerintah perlu ditetapkan sebagai dasar hukumnya. PP 23/2020 merupakan tindak lanjut atas ketentuan tersebut. Secara khusus, PP ini mengatur Program Pemulihan Ekonomi Nasional (PEN) yang merupakan bagian dari serangkaian kebijakan penyesuaian keuangan negara dan kebijakan stabilitas keuangan. Pasal 2 PP ini menjelaskan bahwa Program PEN bertujuan untuk melindungi, mempertahankan, dan meningkatkan kemampuan ekonomi para Pelaku Usaha dalam menjalankan usahanya (Perppu, 2020).

Pada 2020, pemerintah memberikan bantuan presiden (banpres) produktif bagi UMKM senilai Rp2,4 juta. Bantuan melalui Kementerian Koperasi dan UKM ini disalurkan melalui dua tahap yaitu Rp22,01 triliun pada tahap I dan Rp6,81 triliun di tahap II. Hingga akhir tahun, realisasi dari program ini bisa mencapai Rp29,24 triliun atau 99,23 persen dari pagu anggaran sebesar Rp29,47 triliun. Sisa anggaran untuk program ini adalah Rp277,3 miliar atau 0,77\% dari pagu yang disediakan.

Salah satu penerima bantuan adalah para pelaku usaha di Surabaya. Para pelaku usaha mendapat bantuan sebesar Rp2,4 juta yang diberikan melalui bank BRI. Perlu adanya pendampingan agar dana yang diterima oleh para pelaku usaha dapat digunakan dengan sebaik-baiknya sehingga dapat menutup biaya operasional dan kebutuhan untuk berusaha.

Setelah mendapatkan bantuan dari pemerintah, tentu saja mereka harus memiliki kemampuan berpikir kritis untuk menggunakan uang tersebut. Berbagai macam alternatif tentunya dapat mereka lakukan untuk menggunakan uang tersebut, namun perlu adanya keputusan yang membuat uang tersebut berguna untuk kelancaran usaha mereka.

Setiap tindakan manusia dalam kehidupan sehari- hari sesungguhnya didasari oleh keputusan yang diambilnya, keputusan-keputusan yang bersifat rutin biasanya tidak akan berlama-lama dalam mempertimbangkannya. Di luar tindakan rutin tersebut, sering kali dihadapkan pada permasalahan yang perlu dipertimbangkan masak- masak sebelum mengambil keputusan. (D Nachrowi; H Usman, 2004). Salah satu metode pengambilan keputusan adalah menggunakan 
metode PACED (problem, alternatif, criteria, evaluated and decission). Di mana metode ini dikembangkan oleh Yep USAID sebagai metode pengambilan keputusan untuk dapat digunakan untuk segala hal yang memerlukan keputusan yang tepat.

Tujuan dari dilaksanakannya kegiatan pengabdian kepada masyarakat ini adalah: (1) Memberikan pengetahuan mengenai metode PACED dalam mengambil keputusan bagi pada pelaku usaha di Surabaya; (2) Meningkatkan literasi keuangan pelaku usaha.

\section{METODE PELAKSANAAN}

Pelaksanaan kegiatan ini bekerja sama dengan pelaku usaha di Surabaya, dengan menggunakan media Zoom karena tidak dapat diberikan secara offline mengingat kondisi pandemi Covid-19. Pelaku usaha yang dimaksud sebagai objek pelatihan adalah para pemilik usaha yang berasal dari Surabaya dan sekitarnya, tergabung pada suatu komunitas dan berasal dari almamater yang sama. Usaha yang mereka jalankan mulai dari usaha kuliner, usaha fashion, usaha craft, dan jasa.

Awal kegiatan, peserta dikumpulkan dalam satu grup WA dan diberi pengarahan agar lebih mengerti mengenai pelatihan yang kan diselenggarakan. Pelatihan dilaksanakan dengan menggunakan metode partisipatif di mana trainer hanya berfungsi sebagai fasilitator dan mengarahkan peserta menemukan sendiri jawaban atas masalah yang akan digulirkan.

Kegiatan pelatihan online dilaksanakan 4 Desember mulai pukul 18.3020.00. Jumlah peserta 26 orang.

\section{HASIL DAN PEMBAHASAN}

Peserta pelatihan merupakan pelaku usaha yang baru merintis maupun sudah lama melaksanakan kegiatannya. Pada November mereka mendapatkan bantuan permodalan sebesar Rp2.400.000,00 dari pemerintah melalui Bank BRI. Bantuan tersebut harus digulirkan untuk usaha yang mereka lakukan. Peserta yang mengikuti kegiatan ini adalah:

Tabel 1. Peserta Pelatihan

\begin{tabular}{lll}
\hline No. & Keterangan & Jumlah \\
\hline 1. & Jenis Kelamin & \\
& Laki- laki & 7 \\
& Perempuan & 19 \\
2. & Usia & \\
& $18-25$ & 24 \\
& $26-34$ & 2 \\
3. & Bidang Usaha & 12 \\
& Kuliner & 5 \\
& Fashion & 4 \\
& Jasa & 5 \\
& Lainnya &
\end{tabular}

Sumber: Diolah $\overline{(2020)}$ 
Vol. 2, No. 1, March, 2021, pp. 50-56

e-ISSN: 2722-2004

Decision

Making

Training

Utilizing The

PACED

Method

for Business

Players

F. Jumawan,

W. Darmawan,

A. F. Tamrin
Pelatihan diawali dengan pemberian materi tentang tingkatan berpikir kritis yang terdiri dari tiga, yaitu:

1. Tidak berpikir kritis

Percaya pada semua yang didengar dan pada banyak hal tanpa bertanya-tanya.

\section{Kurang berpikir kritis}

Mempertanyakan sebagian besar hal-hal yang dirasa perlu untuk memastikan bahwa informasi yang didengar layak untuk dipercaya.

\section{Berpikir kritis}

Selalu mempertanyakan segala hal, mencari tahu dan mengevaluasi lebih lanjut berdasarkan data dan fakta untuk memastikan bahwa informasi tersebut akurat dan dapat dipercaya (USAID, 2019).

Setelah peserta memahami mengenai tiga tingkatan tersebut, diberikan kuis sebanyak enam soal untuk menguatkan pemahaman peserta mengenai tingkat berpikir kritis tersebut. Tingkatan berpikir kritis diberikan untuk memberikan gambaran kepada peserta bahwa dalam mengambil suatu keputusan harus melalui berpikir kritis agar menghasilkan satu keputusan yang terbaik.

Materi selanjutnya adalah pembahasan Metode PACED, metode ini dikembangkan oleh Yep Usaid untuk memudahkan peserta mengambil keputusan yang diambil. Langkah-langkah PACED ini terdiri dari:

$\mathrm{P}($ Problem $) \quad$ : Tentukan Masalahnya.
A (Alternatifs)
: Daftar Alternatif Pilihan.

$\mathrm{C}($ Criteria $)$

$\mathrm{E}$ (Evaluate) : Evaluasi berbagai Alternatif Pilihan.

D (Decision) : Membuat Keputusan

PACED dipetakan dalam matriks sebagai berikut:

\begin{tabular}{|c|l|l|l|l|l|}
\hline Alternatif/ Criteria & Biaya $<1$ juta & Biaya $>1$ juta & $\begin{array}{c}\text { Waktu berputar } \\
\text { uang }\end{array}$ & $\begin{array}{c}\text { Keberlangsungan } \\
\text { usaha }\end{array}$ & Total \\
\hline $\begin{array}{c}\text { Membeli mesin } \\
\text { produksi }\end{array}$ & & & & & \\
\hline $\begin{array}{c}\text { Memberi bahan } \\
\text { baku }\end{array}$ & & & & & \\
\hline $\begin{array}{c}\text { Membuat konten } \\
\text { digital marketing }\end{array}$ & & & & & \\
\hline $\begin{array}{c}\text { Membuat event } \\
\text { kegiatan }\end{array}$ & & & & & \\
\hline $\begin{array}{c}\text { Keperluan } \\
\text { komsumtif }\end{array}$ & & & & & \\
\hline
\end{tabular}

Sumber: Diolah (2021)

Gambar 1. Matrik PACED pelaku usaha

Selanjutnya, aplikasikan kriteria tersebut ke setiap alternatif pilihan. Salah satu caranya adalah dengan memberi tanda "+" jika alternatif pilihan cocok dengan kriteria, dan berikan tanda "-" jika alternatif tidak cocok dengan kriteria yang ditentukan. Anda bisa memberikan tambahan tanda plus dan minus untuk kriteria yang kamu anggap lebih penting atau sebaliknya (USAID, 2019). Jumlahkan hasil 
KANGMAS: Karya Ilmiah Pengabdian Masyarakat, Vol. 2 No. 1, March 2021 - 61 http://journal.neolectura.com/index.php/kangmas

dari pemberian poin tersebut. Alternatif yang mendapat nilai terbesar merupakan dessicion dari problem. Berikut salah satu hasil dari pengisian oleh peserta:

Tabel 2. Problem: Menentukan Penggunaan Uang Bantuan Dari Pemerintah

\begin{tabular}{|c|c|c|c|c|c|}
\hline $\begin{array}{c}\text { Alternatif/ } \\
\text { Criteria }\end{array}$ & $\begin{array}{c}\text { Biaya } \\
<1 \\
\text { juta }\end{array}$ & $\begin{array}{c}\text { Biaya } \\
>1 \\
\text { juta }\end{array}$ & $\begin{array}{c}\text { Waktu } \\
\text { berputar } \\
\text { uang } \\
\end{array}$ & $\begin{array}{c}\text { Keberlangsungan } \\
\text { usaha }\end{array}$ & Total \\
\hline $\begin{array}{l}\text { Membeli } \\
\text { mesin } \\
\text { produksi }\end{array}$ & + & - & 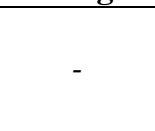 & + & 2 \\
\hline $\begin{array}{l}\text { Memberi } \\
\text { bahan } \\
\text { baku }\end{array}$ & + & - & + & + & 3 \\
\hline $\begin{array}{l}\text { Membuat } \\
\text { konten } \\
\text { digital } \\
\text { marketing }\end{array}$ & + & - & + & ++ & 4 \\
\hline $\begin{array}{l}\text { Membuat } \\
\text { event } \\
\text { kegiatan }\end{array}$ & - & + & - & + & 2 \\
\hline $\begin{array}{l}\text { Keperluan } \\
\text { konsumtif }\end{array}$ & - & + & - & - & 1 \\
\hline
\end{tabular}

Sumber: Diolah (2020)

Hasil penjumlahan paling besar adalah membuat konten digital marketing, sehingga peserta tersebut akan menggunakan Sebagian uang bantuan untuk membuat konten digital marketing karena dinilai mampu untuk membuat keberlangsungan usahanya di masa pandemi ini.

Hasil dari 26 peserta adalah sebagai berikut:

Tabel 3. Hasil Perhitungan Peserta

\begin{tabular}{clc}
\hline No. & Alternatif & Jumlah \\
\hline 1. & Membeli mesin produksi & 3 \\
2. & Memberi bahan baku & 1 \\
3. & Membuat konten digital marketing & 22 \\
4. & Membuat event kegiatan & 0 \\
5. & Keperluan konsumtif & 0 \\
\hline Sumber: Diolah (2020)
\end{tabular}

Dari 26 peserta, 22 peserta memilih untuk membuat konten digital marketing, pemilihan ini didasarkan bahwa pola perilaku konsumen sekarang berpindah dari offline ke online, untuk memasarkan lebih luas mereka memilih membuat konten digital marketing dengan cara mengikuti pelatihan digital marketing.

Dokumentasi pelatihan pengambilan keputusan dengan menggunakan metode PACED: 
Vol. 2, No. 1, March, 2021, pp. 50-56

e-ISSN: 2722-2004

Decision

Making

Training

Utilizing The

PACED

Method

for Business

Players

F. Jumawan,

W. Darmawan,

A. F. Tamrin

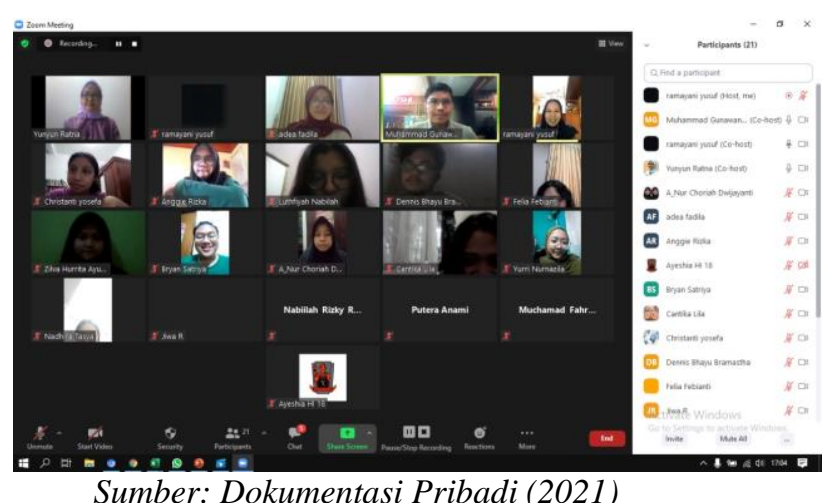

Gambar 2. Kegiatan Pelatihan Online Pengambilan Keputusan

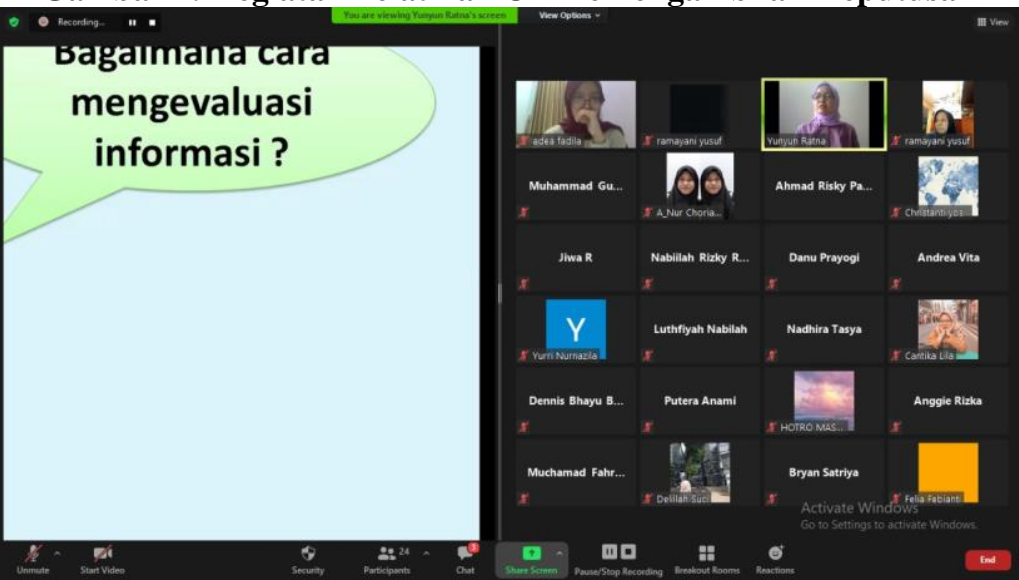

Sumber: Dokumentasi Pribadi (2021)

Gambar 3. Pemberian Materi Pengambilan Keputusan

\section{SIMPULAN}

Pelatihan pengambilan keputusan menggunakan metode PACED dapat memberikan jawaban dan arahan kepada pelaku usaha untuk memanfaatkan bantuan yang mereka dapatkan. Pengambilan keputusan ini juga dapat digunakan untuk masalah-masalah lain yang memerlukan pengambilan keputusan bagi para pelaku usaha. Metode PACED ini cukup mudah dan praktis digunakan dan memberikan hasil yang sesuai dengan keadaan pelaku usaha. Apabila terdapat angka yang sama, pelaku usaha dapat menambahkan beberapa kriteria untuk mendapatkan hasil lebih akurat.

\section{UCAPAN TERIMA KASIH}

Kami selaku penulis mengucapkan terima kasih kepada para pelaku usaha Surabaya, YEP USAID, para trainer Financial Life Skills USAID.

\section{DAFTAR PUSTAKA}

Nachrowi, D., Usman, H. (2004). Teknik Pengambilan Keputusan. Jakarta: Grasindo. 
KANGMAS: Karya Ilmiah Pengabdian Masyarakat, Vol. 2 No. 1, March 2021 - 63 http://journal.neolectura.com/index.php/kangmas

Pakpahan, A. K. (2020). Covid-19 dan implikasi bagi usaha mikro, kecil, dan menengah. Jurnal Ilmiah Hubungan Internasional.

Purnamasari. (2020). Tingkat pengetahuan dan perilaku masyarakat Kabupaten Wonosobo tentang Covid-19. Jurnal Ilmiah Kesehatan, 10(1), 33-42.

USAID. (2019). Modul 5, Berpikir Kritis Dalam Mengambil Keputusan. Jakarta: Yep Project.

KANGMAS is a journal published by

Neolectura, issued three times in one year. KANGMAS is a scientific publication media in the form of conceptual paper and field research related to social service work. It is hoped that KANGMAS can become a media for academics and researchers to publish their social service work and become a reference source for the development of social and humanity.

Our focus: Social Service

Our Scope:

Humanities,

Education,

Management,

History,

Economics,

Linguistics,

Literature,

Religion,

Politics,

Sociology, Anthropology,

and other social service

works. 